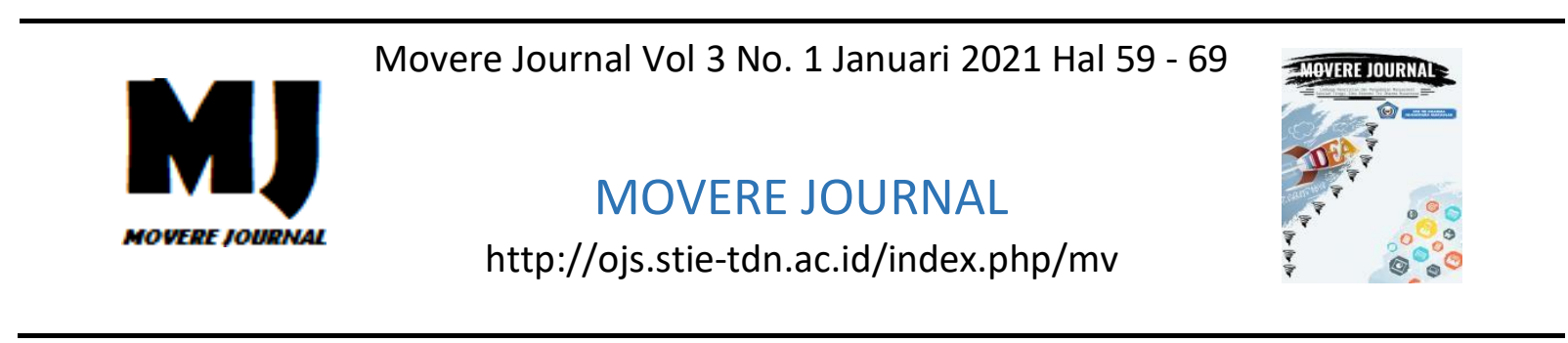

\title{
Analisis Penerapan Potensi dan Efektifitas Pajak Parkir dan Retribusi Parkir Untuk Meningkatkan Pendapatan Asli Daerah Kota Makassar
}

\author{
Ulfa Rabiyah ${ }^{1}$, Firman². \\ Sekolah Tinggi Ilmu Ekonomi Amkop Makassar ${ }^{1,2}$
}

\begin{abstract}
Abstrak : Penelitian ini bertujuan untuk menghitung besaran potensi penerimaan pajak parker, retribusi parkir serta menganalisa efektifitas penerimaan pajak parkir dan retribusi parkir sebagai salah satu sumber Pendapatan Asli Daerah (PAD). Penelitian ini menggunakan pendekatan studi deskriptif yaitu suatu metode peninjauan yang berusaha menggambarkan dan menyajikan keadaan pada saat penelitian berlangsung. Populasi penelitian ini adalah lahan parkir dan wajib pajak parkir yang terdata pada BAPENDA Kota Makassar serta lahan parkir yang dikelola oleh PD. Parkir Makassar Raya. Penarikan Sampel menggunakan metode Stratified Random Sampling dengan Pengelompokan lokasi parkir berdasarkan klasifikasinya masing-masing dan beberapa sampel dari wajib pajak parkir yang secara langsung melakukan pembayaran atas parker. Metode analisis yang digunakan : (1) Analisis Perhitungan Potensi dan (2) Analisis Efektifitas. sangat penting bagi pihak Pemerintah Daerah khususnya Badan Pendapatan Daerah Kota Makassar yang menangani pajak daerah termasuk pajak parkir untuk lebih memperhatikan dan menggali potensi pajak parkir sehingga dapat meningkatkan Pendapatan Asli Daerah Kota Makassar.
\end{abstract}

Kata Kunci: Analisis Potensi ; Efektifitas ; Penerimaan ; Pajak

Abstract : This research aims to calculate the potential amount of parking tax revenue, parking retribution and to analyze the effectiveness of parking tax and parking fees as a source of local revenue. This research uses a descriptive approach which is a review method that seeks to describe and present the situation at the time of the research. The population of this research are the parking area and parking taxpayers recorded at BAPENDA Makassar City as well as parking lots managed by PD. Makassar Raya Parking. The sampling uses is the Stratified Random Sampling method by the classification of parking locations based on their respective classifications and several samples from parking taxpayers who directly make payments for parking. The analysis method used: (1) Potential Calculation Analysis and (2) Effectiveness Analysis. It is very important for the Regional Government, especially the Regional Revenue Agency of Makassar City (Badan Pendapatan Daerah Kota Makassar) which handling local taxes includes parking taxes, to pay more attention and explore the potential for parking taxes so that they can increase the Regional Original Revenue of Makassar City.

Keywords: Potential Analysis; Effectiveness; revenue; Tax 


\section{PENDAHULUAN}

Pungutan Daerah baik berupa Pajak dan Retribusi diatur dengan Undang-Undang Nomor 18 Tahun 1997, sebagaimana telah diubah dengan Undang-Undang Nomor 34 Tahun 2000. Kedua Undang-Undang tersebut kemudian disempurnakan menjadi UndangUndang Nomor 28 Tahun 2009, tentang pajak dan retribusi daerah. Undang-Undang Nomor 28 Tahun 2009 tentang pajak daerah dan retribusi daerah ditetapkan secara utuh pada daerah kabupaten dan kota, yang diselenggarakan atas dasar otonomi yang luas, nyata dan bertanggung jawab. Dengan demikian daerah kabupaten dan kota memiliki kewenangan yang utuh kecuali di bidang pertahanan, keamanan, peradilan, politik luar negeri, moneter dan agama. Dalam rangka pelaksanaan kewenangan pemerintah daerah sebagaimana ditetapkan dalam Undang-undang No 32 Tahun 2004 tentang Pemerintah Daerah yang diikuti dengan Undang-undang No 33 Tahun 2004 tentang perimbangan Keuangan antara Pemerintah Pusat dan Daerah, timbul hak dan kewajiban daerah yang dapat dinilai dengan uang, sehingga perlu dikelola dalam pengelolaan keuangan daerah.

Pajak merupakan pungutan wajib yang harus dibayarkan sebagai bentuk kontribusi warga terhadap Negara yang memiliki sanksi tersendiri ketika seseorang atau warga negara tidak memenuhi kewajibannya atau terlambat membayarnya sedangkan retribusi merupakan pungutan yang tidak wajib, tidak ada sanksi atas tindakan tidak membayar retribusi, hanya saja bagi pihak yang tidak membayar tidak akan mendapatkan jasa sebagaimana yang membayarnya. Ada 11 macam-macam Pajak Daerah yaitu Pajak Hotel, Pajak Restoran, Pajak Hiburan, Pajak
Reklame, Pajak Penerangan Jalan, Pajak Mineral Bukan Logam dan Batuan, Pajak Parkir, Pajak Air Tanah, Pajak Sarang Burung Walet, BPHTB, dan PBB Pedesaan dan perkotaan. Pajak Parkir merupakan salah satu pajak daerah yang berpotensial, artinya hasil pajak parkir berpotensi cukup besar dan baik sebagai sumber pendapatan daerah dalam pertumbuhan ekonomi di daerah. Sebagai salah satu daerah otonom, maka Kota Makassar dalam melaksanakan pembangunan diwujudkan dengan membentuk prakarsa, yaitu dalam menentukan kebijakan, perencanaan, pelaksanaan, dan segi penerimaan pajak daerah.

Kota Makassar merupakan salah satu kota terbesar dan terpadat di Indonesia dan pada saat ini tingkatpendapatan perkapita penduduknya semakin tinggi. Berdasarkan letak wilayahnya, Kota Makassar berpotensi sebagai kota bisnis dan perdagangan. Kota Makassar terkenal sebagai salah satu tujuan kota wisata dan pendidikan di Indonesia bagian timur sehingga banyak orang datang untuk bersekolah dan mencari pekerjaan di kota Makassar. Kota ini semakin padat dan ramai oleh kendaraan yang berlalulalang dijalanan, akibat dari keramaian ini lalu lintas di kota ini sangat macet. Kondisi ini diperparah dengan rendahnya kesadaran masyarakat yang memarkir kendaraannya di atas bahu jalan.

Untuk mengoptimalkan Pendapatan Asli Daerah (PAD), khususnya dari sektor Pajak Parkir dan Retribusi Parkir, pemerintah kota Makassar dalam hal ini Badan Pendapatan Daerah Kota Makassar (Bapenda) yang menyusun kebijakan, pengelolaan, pemantauan, evaluasi serta pembinaan teknis harus bersinergi dengan Perusahaan Daerah Parkir Makassar Raya yang tugas pokoknya 
adalah merencanakan, merumuskan, membina, mengendalikan, mengoptimalkan pemungutan retribusi parkir, serta mengkoordinir kebijakan di bidang perparkiran, sehingga tidak lagi terjadi kesenjangan atau keresahan bagi pengguna jasa parkir dan yang paling utama mampu memberikankontribusi dari sektor pajak parkir dan retribusi parkir.

\section{TINJAUAN PUSTAKA}

\section{A. Pengertian Pajak}

Pajak adalah iuran rakyat kepada kas negara berdasarkan undang-undang sehingga dapat dipaksakan dengan tiada mendapat balas jasa secara langsung. Pajak dipungut penguasa berdasarkan norma-norma hukum untuk menutupi biaya produksi barangbarang dan jasa kolektif untuk mencapai kesejahteraan umum.

Menurut

Adriani

(2011:2), mengemukakan bahwa pajak merupakan iuran kepada negara (dapat dipaksakan) yang terutang oleh yang wajib membayarnya menurut peraturan-peraturan dengan tidak mendapat prestasi kembali yang langsung dapat ditunjuk dan yang gunanya adalah untuk membiayai pengeluaran-pengeluaran umum berhubungan dengan tugas negara untuk menyelenggarakan pemerintahan.

Menurut Rochmat Soemitro (1994:2), mengemukakan definisi pajak sebagai peralihan kekayaan dari pihak rakyat kepada Kas Negara untuk membiayai pengeluaran rutin dan surplusnya digunakan untuk public savingyang merupakan sumber utama untuk membiayai public investment.

\section{B. Pengertian Pendapatan Asli Daerah}

Pendapatan Asli Daerah merupakan salah satu sumber penerimaan daerah yang bertujuan memberikan kewenangan kepada Pemerintah Daerah untuk mendanai pelaksanaan pembangunan dan otonomi daerah sesuai dengan potensi daerah sebagai wujud desentralisasi. Sebagaimana yang dimaksud dalam Undang-Undang No. 33 tahun 2004 tentang Perimbangan Keuangan antara Pemerintah Pusat dan Daerah, Pendapatan Asli Daerah adalah pendapatan yang diperoleh daerah yang dipungut berdasarkan Peraturan Daerah sesuai dengan peraturan perundang-undangan. Sumber Pendapatan Asli DaerahBerdasarkan UU No. 33 tahun 2004 tentang Perimbangan Keuangan antara Pemerintah Pusat dan Pemerintah Daerah, PAD bersumber dari :1) Pajak Daerah, 2) Retribusi Daerah dan 3) Hasil pengelolaan kekayaan daerah yang dipisahkan; danPendapatan Asli Daerah lainlain yang sah.

\section{Pengertian Pajak Daerah}

Pada tahun 1997, Pemerintah akhirnya mengeluarkan Undang-Undang Nomor 18 Tahun 1997 sebagaimana yang telah diubah dengan Undang-Undang Nomor 34 Tahun 2000 dan Undang-Undang 28 tahun 2009 tentang pajak daerah dan retribusi daerah, Pajak Daerah, yang selanjutnya disebut Pajak, adalah kontribusi wajib kepada Daerah yang terutang oleh orang pribadi atau badan yang bersifat memaksa berdasarkan Undang-Undang, dengan tidak mendapatkan imbalan secara langsung dan digunakan untuk keperluan Daerah bagi sebesarbesarnya kemakmuran rakyat. Sumbersumber penerimaan daerah yaitu:1) Pendapatan Asli Daerah (PAD), 2) Dana Perimbangan, 3) Bagi Hasil Pajak dan Bukan Pajak, 4) Dana Alokasi Umum (DAU), 5) Dana Alokasi Khusus (DAK), 6) Pinjaman Daerah (Pembiayaan), 7)Lain-Lain Penerimaan yang Sah, 8) Hibah dan 9) Dana darurat lainnya. 


\section{Pengertian Retribusi Daerah}

Menurut UU No. 28 Tahun 2009 tentang retribusi daerah, yang dimaksud dengan retribusi daerah adalah pungutan daerah sebagai pembayaran atas jasa atau pemberian ijin tertentu yang khusus disediakan dan atau diberikan oleh pemerintah daerah untuk kepentingan orang pribadi atau badan.

Retribusi adalah pembayaran wajib dari penduduk kepada negara karena adanya jasa tertentu yang diberikan oleh negara kepada penduduknya secara perorangan. Jasa tersebut dapat dikatakan bersifat langsung, yaitu hanya pembayar retribusi yang dapat menikmati balas jasa dari negara. Sesuai dengan ketentuan perundang-undangan yang berlaku di Indonesia, saat ini penarikan retribusi hanya dapat dipungut oleh pemerintah daerah. (Siahaan, 2010:7)

Berdasarkan UU No. 28 Tahun 2009 retribusi daerah adalah pungutan daerah sebagai pembayaran atas jasa atau pemberian ijin tertentu yang khusus disediakan dan atau diberikan oleh pemerintah daerah untuk kepentingan orang pribadi atau badan. Jasa adalah kegiatan pemerintah daerah berupa usaha dan pelayanan yang menyebabkan barang, fasilitas, atau kemanfaatan lainnya, dapat dinikmati oleh orang pribadi atau badan. Dengan begitu bila seseorang ingin menikmati jasa yang disediakan oleh pemerintah daerah, maka ia harus membayar retribusi yang ditetapkan sesuai dengan ketentuan yang berlaku.

\section{E. Parkir}

Menurut Pasal 1 angka 6 Peraturan Daerah Makassar Nomor 17 Tahun 2006 Tentang Pengelolaan Parkir Tepi Jalan Umum Dalam Kota Makassar, Parkir adalah memberhentikan dan menempatkan kedaraan bermotor di tepi jalan umum yang bersifat sementara pada tempat yang telah ditetapkan.
Sedangkan menurut Keputusan Menteri Perhubungan Nomor : KM 66 Tahun 1993 Tentang Fasilitas Parkir untuk Umum, yaitu Pasal sebagai berikut :

- Parkir adalah keadaan tidak bergerak suatu kendaraan yang tidak bersifat sementara;

- Fasilitas Parkir di luar badan jalan adalah fasilitas parkir kendaraan yang dibuat khusus yang dapat berupa taman parkir dan/atau gedung parkir.

- Fasilitas Parkir untuk umum adalah fasilitas parkir di luar badan jalan berupa gedung parkir atau taman parkir yang diusahakan sebagai kegiatan usaha yang berdiri sendiri dengan menyediakan jasa pelayanan parkir untuk umum.

\section{F. Pajak Parkir,}

Menurut Undang-Undang Republik Indonesia No 28 Tahun 2009 Tentang Pajak Daerah dan Retribusi Daerah sebagaimana dimuat oleh Peraturan Daerah Kota Makassar Nomor 13 Tahun 2002 "Pajak parkir adalah pungutan yang dikenakan atas penyelenggaraan usaha tempat parkir yang dikelola Orang atau Badan”.

Objek Pajak Parkir adalah penyelenggaraan tempat Parkir di luar badan jalan, baik yang disediakan berkaitan dengan pokok usaha maupun yang disediakan sebagai suatu usaha, termasuk penyediaan tempat penitipan kendaraan bermotor dan garasi kendaraan bermotor yang memungut bayaran.

\section{G. Retribusi parkir}

Retribusi parkir merupakan pungutan yang dikenakan pada pemakai kendaraan yang memarkir kendaraannya di ruang parkir. Lalu lintas yang bergerak baik yang bergerak lurus maupun belok pada suatu saat akan berhenti. Setiap perjalanan akan sampai ketempat tujuan, dan kendaraan yang dibawa 
akan di parkir atau bahkan akan ditinggal pemiliknya di ruang parkir. Kontribusi dalam bentuk retribusi daerah yang diterima oleh Pemerintah Daerah berbeda dengan daerah lainnya tergantung dari potensi yang dimiliki oleh daerah itu sendiri.

\section{H. Potensi Penerimaan}

Potensi Penerimaan Retribusi Parkir adalah taksiran pendapatan retribusi parkir yang diperoleh per hari dapat dihitung dengan mengalikan volume parkir yang terjadi dengan tarif yang berlaku. Sedangkan untuk lokasi yang menggunakan tarif progresif, perhitungan taksiran pendapatan retribusi parkir per hari di lakukan dengan cara mengalikan tarif parkir yang berlaku tiap jamnya dengan jumlah kendaraan parkir dengan durasi tertentu (Septianawati, 2012:38).

\section{Efektifitas}

Menurut Kamus Besar Bahasa Indonesia, kata efektif mempunyai arti efek, pengaruh, akibat atau dapat membawa hasil. Menurut Bayangkara (2014:14). Pengertian efektifitas dapat dipahami sebagai tingkat keberhasilan suatu perusahaan untuk mencapai tujuannya. Sehingga dapat dikatakan, efektifitas adalah suatu ukuran yang menyatakan seberapa jauh target (kuantitas, kualitas dan waktu) yang telah dicapai oleh organisasi, yang mana target tersebut sudah ditentukan terlebih dahulu.

\section{III.METODE PENELITIAN}

\section{A. Waktu dan Lokasi Penelitian}

Penelitian ini dilaksanakan selama 1 tahun dari bulan Januari - Desember 2020 di Kantor Badan Pendapatan Daerah Kota Makassar dan PD. Parkir Makassar Raya dengan pertimbangan bahwa baik data maupun informasi yang dibutuhkan mudah diperoleh serta relevan dengan pokok permasalahan yang menjadi objek pokok penelitian.

\section{B. Jenis dan Sumber Data}

Jenis dan sumber data yang digunakan dalam penelitian ini adalah data primer dan sekunder. Teknik pengumpulan data yaitu observasi, dokumentasi dan wawancara.

\section{Populasi dan Sampel}

Populasi dalam penelitian ini adalah lahan parkir dan wajib pajak parkir yang terdata pada BAPENDA Kota Makassar serta tempat parkir yang dikelola oleh PD. Parkir Makassar Raya. Penelitian ini menggunakan Stratified Random Sampling. Pengelompokan lokasi parkir diambil berdasarkan klasifikasinya masing-masing. Beberapa sampel dari wajib pajak parkir yang secara langsung melakukan pembayaran atas parkir pada BAPENDA dan PD.

\section{Pengolahan dan Analisis Data}

Penelitian ini menggunakan pendekatan studi deskriptif kualitatif yaitu suatu sistem pemikiran atau suatu metode peninjauan yang berusaha menggambarkan dan menyajikan keadaan pada saat penelitian berlangsung. Penelitian ini bertujuan untuk menggambarkan tentang potensi pajak parkir dan retribusi parkir sebagai salah satu sumber Pendapatan Asli Daerah (PAD). Adapun analisis yang digunakan

\section{Analisis Perhitungan Potensi}

Analisis perhitungan potensi mutlak diperlukan dalam analisis menetapkan target rasional. Analisis perhitungan potensi mutlak diperlukan dalam analisis menetapkan target rasional. Dengan potensi yang ada, setelah dibandingkan penerimaan untuk masa yang akan datang, maka akan didapatkan besarnya potensi yang terpendam, sehingga akan dapat diperkirakan rencana tindakan apa yang akan dilakukan untuk menggali potensi yang terpendam tersebutuntuk menentukan berapa 
besarnya rencana penerimaan yang akan datang.

\section{Menghitung Potensi Retribusi Parkir :}

Perhitungan potensi penerimaan retribusi parkir dalam satu hari dapat dilihat dari jumlah kendaraan yang parkir dikalikan dengan tarif parkir yang berlaku. potensi penerimaan retribusi parkir dapat dihitung dengan rumus :

$P R P=365 \times\{(\operatorname{SRP} x$ Imotor $x t)\}+(\operatorname{SRP} x$ Imobil $x t$ )

Dimana :

PRP = Potensi Retribusi Parkir

SRP = Satuan Ruang Parkir

Imotor $=$ Rata-rata Intensitas motor yang Parkir

Imobil =Rata-rata Intesitas mobil yang Parkir $\mathrm{T} \quad=$ Tarif Parkir yang berlaku

\section{Analisis Efektifitas}

Efektivitas merupakan kemampuan untuk memilih tujuan yang tepat atau peralatan yang tepat untuk pencapaian tujuan yang ditetapkan. Selanjutnya efektivitas harus dinilai atas tujuan yang bisa dilaksanakan dan bukan atas konsep tujuan yang maksimum (Yasin, N. A., Ridjal, S., \& Jjufri 2019) Jadi, efektivitas menurut ukuran seberapa jauh organisasi berhasil mencapai tujuan yang layak dicapai. Efektivitas secara harfiah, diartikan pengaruh dan mempunyai daya guna serta membawa hasil. Tax effectiveness merupakan perbandingan antara penerimaan pajak aktual dengan potensi penerimaan pajak. Efektivitas pajak secara tidak langsung menunjukkan seberapa besar keberhasilan daerah dalammengumpulkan pajak dari potensi yang dimilikinya. Berikut langkah-langkah perhitungan efektivitas pajak parkir dan retribusi parkir :

1. Membagi realisasi penerimaan pajak parkir dengan target penerimaan pajak parkir dan membagi penerimaan retribusi parkir dengan target penerimaan retribusi parkir.

2. Setelah diperoleh hasil bagi dari realisasi dan target pajak parkir dan retribusi parkir kemudian dikalikan dengan $100 \%$.

3. Hasil prosentase yang didapat kemudian dibandingkan dengan kriteria efektivitas.

Langkah-langkah diatas dapat dirumuskan sebagai berikut:

Untuk pajak parkir :

$$
\begin{aligned}
& \text { Efektifitas }= \\
& \frac{\text { Realisasi Penerimaan Pajak Parkir }}{\text { TargetPenerimaan Pajak Parkir }} \times 100 \%
\end{aligned}
$$

Untuk retribusi parkir :

Efektifitas $=$

$\frac{\text { Realisasi Penerimaan Retribus Parkir }}{\text { Target Penerimaan Retribusi Parkir }} \times 100$

Rumus tersebut menggambarkan kemampuan pemerintah dalam merealisasikan retribusi parkir yang telah direncanakan dengan target yang telah ditetapkan sebelumnya.

Berikut kriteria efektivitas:

\section{Tabel 1. Kriteria Efektifitas}

\begin{tabular}{|c|c|}
\hline Prosentase & Kriteria \\
\hline$>100 \%$ & Sangat Efektif \\
$>90 \%-100 \%$ & Efektif \\
$>80 \%-90 \%$ & Cukup Efektif \\
$>60 \%-80 \%$ & Kurang Efektif \\
$>60 \%$ & Tidak Efektif \\
\hline
\end{tabular}

3. Data yang telah dikumpulkan melalui observasi, wawancara dan studi pustaka dalam penelitian ini selanjutnya akan dianalisis melalui metode kombinasi (Mixed Method). Metode ini ditujukan untuk memahami gejala masalah yang diteliti dengan menekankan pada permasalahan pokok, mengenai proses 
pengelolaan retribusi parkir yang merupakan bagian dari pendapatan asli daerah (PAD) yang difokuskan di Kantor PD Parkir Makassar Raya, serta kajian futuristik dalam upaya terciptanya manajemen pengelolaan yang baik dalam penyelenggaraan negara dan pemerintahan.

\section{HASIL ANALISIS DAN PEMBAHASAN}

\section{A. Pajak Parkir}

\section{Penerimaan Pajak Parkir di Kota Makassar}

Setelah melakukan observasi dibeberapa Wajib Pajak Parkir yang terdaftar di Badan Pendapatan Daerah Kota Makassar, peneliti mengambil kurang lebih 12 (dua belas) Wajib Pajak Parkir yang menggunakan sistem timer sesuai dengan data yang diperoleh langsung dari Badann Pendapatan Daerah Kota Makassar diantaranya, yaitu Trans Kalla Makassar/Trans Studio Makassar, Manggala Junction, Living Plaza Pettarani, Hotel Four Points Makassar, Rumah Sakit Awal Bros, Rumah Sakit Grestelina, Menara Bosowa, Upper Hils Makassar, Mall Panakkukang, Swissbell Hotel, Pasar Segar Makassar dan Ruko Pettarani.

Dari beberapa Wajib Pajak tersebut adapun penetapan pajak dilakukan dengan lebih dulu menerbitkan SPTPD (Surat Pemberitahuan Pajak Daerah) untuk self assessment yang diterbitkan oleh BAPENDA Kota Makassar lalu diberikan ke masingmasing wajib pajak (pengelola parkir). Pembayaran pajak parkir di Kota Makassar dilakukan di BAPENDA Kota Makassar yang menerima ialah Bendahara Penerimaan Pajak. Pembayaran dilakukan dengan menggunakan SSPD (Surat Setoran Pajak
Daerah). Penagihan pajak dilakukan oleh bagian penagihan jika utang pajak belum dibayar atau terjadi kurang bayar.

Dari wawancara dengan Bapak Kepala Sub. Bidang Penetapan dan Pelaporan Pajak \& Retribusi Daerah Bidang II Pajak Parkir diketahui bahwa sistem pemungutan pajak parkir di Kota Makassar hanya menggunakan satu sistem. Adapun hasil wawancaranya sebagai berikut:

"Sejak September 2012 sistem pemungutan pajak parkir sudah menggunakan satu sistem yaitu dengan self assessment dimana wajib pajak diberikan kepercayaan untuk menghitung, memperhitungkan, membayar dan melaporkan sendiri pajak yang terutang dengan menggunakan SPTPD. Dan ada sekitar 12 wajib pajak parkir yang menggunakan timer dengan sistem self assessment."

Dari hasil wawancara diatas dapat dikatakan bahwa Wajib Pajak sudah mudah melaporkan penerimaan pajak parkir ke BAPENDA Kota Makassar karena menggunakan satu sistem yaitu self assessment. Diketahui pula bahwa dari 12 (dua belas) Wajib Pajak yang dijadikan sampel tersebut setidaknya aktif menyetor tepat waktu dan paling berpotensial dalam menggali sumber penerimaan khususnya perparkiran yang ada pada sejumlah wilayah di Kota Makassar.

\section{Analisis Potensi Penerimaan Pajak Parkir di Kota Makassar}

Potensi pajak parkir di Kota Makassar jika dilihat secara keseluruhan dapat dilihat dengan menggunakan indikator jumlah wajib pajak parkir dan jumlah kendaraan bermotor sebagai subjek parkir yang ada di Kota Makassar. Berikut ini disajikan jumlah kendaraan bermotor di Kota Makassar. 
Data pertumbuhan bermotor di Kota Makassar pada tahun 2019 yaitu sebanyak 1.488.005 unit, ini menandakan bahwa jumlah kendaraan di Kota Makassar berkembang pesat seiring dengan meningkatnya perekonomian di Kota Makassar mulai dari sektor pelayanan jasa maupun sektor perindustrian. Hal ini tentunya berdampak langsung pada penerimaan pajak parkir, oleh karena itu sangat penting bagi pihak Pemerintah Daerah khususnya Badan Pendapatan Daerah Kota Makassar yang menangani pajak daerah termasuk pajak parkir untuk lebih memperhatikan dan menggali potensi pajak parkir sehingga dapat meningkatkan Pendapatan Asli Daerah Kota Makassar.

Berdasarkan data sekunder yang diamati oleh peneliti dari sekitar kurang lebih 692 titik wajib pajak parkir yang ada di Kota Makassar, sekiranya peneliti mengambil 12 titik wajib pajak parkir yang menggunakan timer. Perhitungan potensi timer akan dijabarkan sebagai berikut:

Dari hasil wawancara dengan Kepala Sub. Bidang Penetapan dan Pelaporan Pajak \& Retribusi Daerah mengatakan bahwa :

"Potensi dapat ditambahkan 30\% dari realisasi pajak parkir yang diterima oleh BAPENDA sedangkan estimasi jumlah kendaraan bermotor yang parkir tiap harinya yaitu $45 \%$ mobil dan 55\% motor dengan rata-rata tarif yang digunakan sebesar Rp 3.000-,/motor Rp 5.000,/mobil". (Wawancara, 2020)

Adapun tarif yang ditetapkan adalah :

Mobil :Jam Pertama Rp 3.000

Jam Kedua $\quad$ Rp 5.000

Jam Ketiga $\quad$ Rp 7.000

Motor : Jam Pertama $\quad$ Rp 2.000

Jam Kedua $\quad$ Rp 3.000

Jam Ketiga $\quad$ Rp 4.000

\section{B. Retribusi Parkir}

1. Penerimaan Retribusi Parkir di Kota Makassar

Perusahaan Daerah Parkir Makassar Raya yang berjalan aktif setelah dikuatkan dengan Surat Keputusan Walikota Nomor 935/kep/188.342/2006 menunjuk direksi Perusahaan Daerah Parkir Makassar Raya untuk menyusun petunjuk teknis dalam melaksanakan kewenangannya menetapkan titik/tempat-tempat parkir, pembagian tempat parkir, pengelompokan jenis kendaraan pengguna tempat dan jasa parkir, penggunaan areal pelataran parkir, tanda/garis tempat parkir, struktur tarif jasa parkir, pemasangan dan pemanfaatan fasilitas parkir.

Sama halnya dengan penerimaan pajak parkir, peneliti juga melakukan observasi dibeberapa wilayah di Kota Makassar. Beberapa sampel tersebut mewakili beberapa ruas area jasa perparkiran yang ada di Kota Makassar, dimana ada beberapa sektor jasa perparkiran yang dikelola atau dipantau langsung oleh pihak Perusahaan Daerah Parkir Makassar Raya diantaranya, yaitu yang termasuk dalam Parkir Tepi Jalan Umum (Makassar Town Square dan Mall Panakkukang), yang termasuk dalam Parkir Insidentil (Toko Alaska), yang termasuk dalam Parkir Komersial (Pasar SudiangMandai), dan yang termasuk dalam Parkir Langganan Bulanan (Jalan Raden Ajeng Kartini).

Oleh karena pemungutan parkir dikelola oleh perusahaan daerah parkir berarti perusahaan daerah parkir yang berkaitan dengan pendirian, operasional, dan pengangkatan pegawainya tunduk pada ketentuan dan tata cara yang diatur dalam Undang-Undang Nomor 5 Tahun 1962. Terselenggaranya pengawasan dalam sebuah 
institusi yakni untuk menilai kinerja suatu institusi dan memperbaiki kinerja sebuah institusi. Oleh karena itu dalam setiap perusahaan mutlak bahkan rutin adanya sistem pengawasan.

Dari wawancara dengan Bapak Direktur Operasional PD.Parkir Makassar Raya diketahui bahwa:

"Sistem pemungutan retribusi parkir di Kota Makassar tidak semata-mata hanya untuk memungut tetapi bagaimana kedepannya pihak PD. Parkirterus melakukan upaya dalam menggali potensi penerimaan retribusi parkir agar dapat meningkatkan pendapatan asli daerah Kota Makassar khususnya di jasa perparkiran".(Wawancara, 2020)."

Dari hasil wawancara diatas dapat dikatakan bahwa pihak PD Parkir Makassar Raya Kota Makassar terus berupaya menggali potensi penerimaan parkir agar dapat meningkatkan pendapatan asli daerah di Kota Makaasar. Namun bukan hanya dalam hal meningkatkan sumber penerimaan tetapi bagaimana kedepannya tidak terjadi ha-hal yang dapat merugikan baik itu masyarakat yang secara langsung menggunakan dan membayar retribusi parkir, maupun pihak PD. Parkir dalam hal ini menerima serta mengelola retribusi parkir yang kemudian digunakan secara tidak langsung untuk meningkatkan Pendapatan Asli Daerah Kota Makassar.

\section{Analisis Potensi Penerimaan Retribusi Parkir di Kota Makassar}

Penelitian ini memerlukan waktu pengumpulan data selama satu tahun. Waktu observasi untuk survei lokasi, melakukan pengamatan, dan mengumpulkan data pada setiap lingkungan parkir memiliki waktu yang bervariatif, hal ini bertujuan untuk mendapatkan informasi frekuensi jumlah kendaraan dan intensitas penggunaan setiap ruang parkir. pemilihan waktu tersebut diharapkan dapat mewakili waktu efektif yang dapat mewakili satu tahun yaitu 269 hari weekday dan 96 hari weekend. Adapun perhitungan untuk menghitung potensi penerimaan retribusi parkir sebagai berikut:

$P R P=269 \mathrm{x}\left\{\left(\sum S R P \times\right.\right.$ Imotor $\left.x t\right)+\left(\sum S R P x\right.$ Imobil $x$

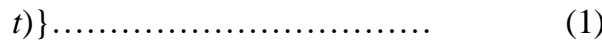

$P R P=96 x\left\{\left(\sum S R P \times\right.\right.$ Imotor $\left.x t\right)+\left(\sum S R P x\right.$ Imobil $x$

t) $\} \ldots \ldots \ldots \ldots \ldots \ldots \ldots \ldots \ldots$

Intensitas motor dan Intensitas mobil $=\frac{\boldsymbol{J}}{\boldsymbol{K}}$

Dimana:

PRP = Potensi Retribusi Parkir

SRP = Satuan Ruang Parkir

Imotor =Intensitas motor yang Parkir

Imobil =Intensitas mobil yang parkir

$\mathrm{T}=$ Tarif parkir yang berlaku

JK = Jumlah Kendaraan

\section{KESIMPULAN DAN SARAN}

\section{A. Kesimpulan}

Makassar dengan berkembang yang cukup pesat seiring dengan meningkatnya perekonomian mulai dari sektor pelayanan jasa maupun sektor perindustrian berdampak langsung pada penerimaan pajak parkir, oleh karena itu sangat penting bagi pihak Pemerintah Daerah khususnya Badan Pendapatan Daerah Kota Makassar yang menangani pajak daerah termasuk pajak parkir untuk lebih memperhatikan dan menggali potensi pajak parkir sehingga dapat meningkatkan Pendapatan Asli Daerah Kota Makassar.

\section{B. Saran}

Perlunya penghitungan potensi secara dinamis mengingat potensi Pajak Parkir dan Retribusi Parkir di Kota Makassar senantiasa berkembang seiring dengan perkembangan perekonomian Kota Makassar dan potensi yang ada sebaiknya dioptimalkan dengan baik untuk peningkatan pajak daerah dan pendapatan asli daerah kota Makassar. Diperlukan juga perlu peningkatkan 
pemahaman aspek pekerjaan, dan positif dari masyarakat, kalua distribusi parker ini digunakan untuk pembangunan kota Makssar. (Nur 2021). Komponen fungsional yang meliputi perencanaan, pengendalian, serta koordinasi antar anggota dan pimpinan juga perlu untuk diperhatikan (Rostini et al. 2020)

\section{DAFTAR PUSTAKA}

(1) Azhari, A. Samudra, 1990, Perpajakan di Indonesia, Jakarta: PT. Gramedia.

(2) Aristanti Widyaningsih, 2011, Hukum Pajak dan Perpajakan. Bandung: Alfabeta.

(3) (3) Azwar, Saifudin, 2010, Metode Penelitian, Yogyakarta: Pustaka Pelajar.

(4) Keputusan Menteri Dalam Negeri No. 690.900.327 tahun 1996 Tentang Pedoman Penilaian dan Kinerja Keuangan.

(5) Mardiasmo, 2013,Perpajakan, Yogyakarta: Edisi revisi.

(6) Nur, A. 2021. "Transglobal Leadership as a Driver for Increasing the Employee Performance." International Journal of Organizational Leadership 10(1):54-71. doi: 10.33844/ijol.2021.60517.

(7) Poerwadarminta, W.J.S, 2003, Kamus

\section{Umum Bahasa \\ Indonesia,}

Jakarta

Balai Pustaka.

(8) Prakosa, Kesit Bambang, 2005, Pajak dan Retribusi DaerahCet II, Yogyakarta: UII Press.

(9) Peraturan Daerah Kota Makassar Nomor 2 Tahun 2018 tentang Pajak Daerah Kota Makassar.

(10) Peraturan Daerah Kota Makassar No 13 Tahun 2002 Tentang Pajak Parkir.

(11) Peraturan Daerah Kota Makassar No 17 Tahun 2006 Tentang
Pengelolaan Parkir Tepi Jalan Umum Dalam Daerah Kota Makassar.

(12) Rosidin, Utang, 2015, Otonomi Daerah dan Desentralisasi, Bandung: CV Pustaka Setia.

(13) Rostini, R., W. Souisa, R. Masmarulan, and N. Yasin. 2020. "Competitiveness Development, Learning Orientation, Entrepreneurial Commitment and Business Performance in the Silk. Industry." Management Science Letters 11(3):9038.doi:10.5267/j.msl.2020.10.008

(14) Siahaan, Marihot P, 2016, Pajak Daerah dan Retribusi Daerah, Depok: Raja Grafindo Persada.

(15) Suparmoko, M, 2000, Ekonomi Publik, Edisi Pertama, Yogyakarta: Penerbit Andi.

(16) Sugiyono, 2014, Metode Penelitian Kuantitatif Kualitatif dan $R \& D$, Bandung: Alfabeta.

(17) TMbook, 2013, Perpajakan Esensi dan Aplikasi, Yogyakarta: CV Andi Offs.

(18) Undang-Undang Dasar Negara Republik Indonesia Tahun 1945.

(19) Undang-Undang No. 34 tahun 2000 tentang Pajak dan Retribusi Daerah.

(20) Undang-Undang No. 32 tahun 2004 tentang Pemerintahan Daerah

(21) Undang-Undang No. 33 tahun 2004 tentang Perimbangan Keuangan antara Pemerintah Pusat dengan Pemerintah Daerah

(22) Undang-Undang No. 28 Tahun 2009 tentang Pajak Daerah dan Retribusi Daerah.

(23) Waluyo, 2007, Perpajakan di Indonesia Buku 2, Jakarta: Salemba Empat.

(24) Yani, Ahmad, 2008, Hubungan Keuangan Daerah antara Pemerintah Pusat dan Daerah, Jakarta: Rajawali Press. 
(25) Yasin, N. A., Ridjal, S., \& Jjufri, M.

2019. "Human Capital and

Entrepreneurship and Their Impact

on the Productivity of Traditional

Craftsmen." Revista ESPACIOS

40(04). 